Expounding the Mathematical Seed: A Translation of Bhāskara I on the Mathematical Chapter of the Āryabhatīya by Agathe Keller

Science Networks: Historical Studies 30-31. Basel/Boston/Berlin: Birkhäuser Verlag, 2006. Pp. liii+172, xii+240. ISBN 3-7643-7291-5 and 3-7643-7299-0. Cloth $\$ 218.00$

\author{
Reviewed by \\ S. R. Sarma \\ formerly Aligarh Muslim University \\ srsarma@gmx.net
}

Towards the close of the fifth century AD - to be precise, in AD 499 Âryabhata composed at the young age of 23 years a work in Sanskrit which he named simply Āryabhațiya or Āryabhata's Work. Consisting of just 121 couplets spread over four chapters, it is the first extant text on mathematical astronomy in India. In keeping with the general style of śästras (i.e., systematized corpora of knowledge), the text is extremely concise and would remain unintelligible without the explanations by a teacher or a commentary. In the subsequent centuries, therefore, several commentaries came to be written on this fundamental text.

Among such commentaries, the earliest extant one was composed by Bhāskara I in 629 at Valabhī in the modern state of Gujarat. Bhāskara could not have been Āryabhața's direct pupil, but he certainly belonged to the circle of the latter's followers; and his commentary was held in great esteem by all the subsequent commentators who made avid use of it. Besides this commentary, Bhāskara also authored two original treatises: the Mahäbhāskariya (The Larger Work by Bhāskara) and the Laghubhāskarìya (The Smaller Work by Bhāskara). In these two works, as in the commentary, he follows generally Âryabhata's school of astronomy, but does not subscribe to the master's theory of the earth's diurnal rotation [Chatterjee 1974].

The second chapter of the Aryabhatīya, consisting of 33 verses, is entitled Ganitap $\bar{a} d a$ and is devoted to mathematics. The arithmetic and geometry discussed here are more extensive than what is required for the astronomical computations envisaged in the other

(C) 2006 Institute for Research in Classical Philosophy and Science All rights reserved

ISSN 1549-4497 (online) ISSN $1549-4470$ (print) ISSN 1549-4489 (CD-ROM) 
chapters. Therefore, this chapter can be seen as an independent treatise on mathematics, indeed, as one of the earliest extant treatises on mathematics. In his commentary on this chapter on mathematics, as in his commentary on the other chapters, Bhāskara analyses the syntax of the terse sentences of the original, explains the literal meaning, investigates the possibility of alternative interpretations, anticipates and refutes possible objections to the issue at hand, expounds the mathematical procedures, offers suitable examples, and solves them. Sometimes for a single rule he gives several examples. In fact, the commentary on this chapter contains as many as 120 examples with their solutions. Thus, the commentary on this chapter documents, for the first time, the mathematical practice in India in the early seventh century.

Therefore, it is highly commendable that Agathe Keller devotes her study to Bhāskara's commentary on the mathematical chapter of the A ryabhatìya. Her study consists of two volumes. The first volume contains an introduction and an English translation of Āryabhata's verses as well as Bhāskara's commentary on them, while the second volume is devoted to the analysis of this commentary.

The long introduction preceding the translation discusses in detail the contents of Bhāskara's commentary, its structure and its method of exposition. It is stated that, according to Bhāskara, "the rule given in the treatise is a seed (bija) which the commentator expounds' [1.xli]. This explains the title of the present work.

Coming to the actual translation, it must be stated right away that it is not an easy task to translate Sanskrit commentaries into non-Indian languages, because the commentator, like a teacher in the class room, first analyses the syntax and grammar of the primary text, gives a word-by-word meaning, and then explicates the original author's statement - all this with copious citations from diverse authorities. During the past two centuries since the time Colebrooke [1817] translated into English the mathematical chapters of Brahmagupta's Brāhmaspuțasiddhāta and Bhāskara II's Lìlāvatī, several Sanskrit works on mathematics and astronomy have been translated into English and other Europeans languages, but so far no commentary has been fully rendered into English. This is so not because Indologists 'privilege treatise over its commentaries', as Keller unfairly accuses them [xxvi], but because the peculiar style adopted 
in the Sanskrit commentaries does not easily lend itself to translation. The importance of the commentaries in all branches of Sanskrit learning has been recognized and evaluated, both in the Indian tradition and by modern Indology. In fact, western Indology could not have come into being without the commentaries paving the way for the understanding of basic Sanskrit texts. In the Indian tradition too, commentaries are looked upon with due respect. Commentators like Patañjali in the field of grammar, ${ }^{1}$ Sankara in philosophy, Abhinavagupta in poetics and dramaturgy, Mallinātha in poetry are household names in India. Keller's statement 'A similar disregard of commentaries can also be found in the field of history of mathematics' $[\mathrm{xvi}$ ] is therefore unwarranted. Colebrooke, the first modern scholar of Indian mathematics, in his work just mentioned, gives copious citations from various commentaries on Brahmagupta's Brāhmasphuțasiddhānta and on Bhāskara II's Lìlāvatī. Bibhutibhusan Datta in his Science of the Sulba [Datta 1932], and Bibhutibhusan Datta and Avadhesh Narayan Singh in their History of Hindu Mathematics [Datta and Singh 1935-1938] have given as much importance to commentaries as they did to the primary texts. In the last decade, the Japanese scholars Hayashi, Kusuba, and Yano have published excellent studies based on Nīlakaṇtha's commentary of the Áryabhațiya, together with annotated translations of several large extracts from this commentary [Hayashi, Kusuba, and Yano 1997].

Be that as it may, the book under review is the first attempt to translate a Sanskrit commentary on a mathematical text fully, and it deserves to be recognized as a pioneering venture. The text of the commentary was edited and published in 1976 by Kripa Shankar Shukla [Shukla 1976] who made a name for himself with the publication of several Sanskrit mathematical and astronomical texts, and with his meticulous studies. The manuscript material used by him was rather meagre and was removed by about 1000 years from Bhāskara's time. In the circumstances, Shukla reconstructed the text in an exemplary manner. Even so, there remain some passages which were poorly transmitted, or the reconstruction of which is not wholly

1 I fail to understand what made Keller denigrate this commentary by writing, 'An infamous grammatical commentary authored by Patañjali, that all educated Indian pandits knew' [xlii n109: emphasis added]. Certainly nothing that she has written on this commentary, nor, for that matter, anything anybody ever wrote on it could lead to such a judgment. 
satisfactory. Keller has sought to improve the text of the commentary by going back to the palm leaf manuscripts written in Malayalam characters and has succeeded in some cases.

The translation which she provides for Âryabhata's rules and Bhāskara's commentary is reasonably accurate and reliable, but sometimes it tends to be too literal, giving preference to the primary or etymological sense of a term rather than to its contextual meaning. Thus, the primary meaning of the Sanskrit word karna is no doubt 'ear', but it has also the secondary meaning of 'hypotenuse' in a geometrical context. There is no particular virtue in rendering karna throughout as the 'ear' in this translation [27 et passim]. After all a translator must pay attention to the author's intention; it is certain that Bhāskara, when he used karṇa, thought of the hypotenuse and not of the ear.

Sometimes the translation lays the wrong emphasis. The translation of the very first benedictory verse of the commentary is marred by such misplaced emphasis:

\section{yan-nāma-samsmaraṇa-mātra-bhavābhavāni śreyo'śubhāni}

Homage to that Siva whose name, only when meditated upon, creates and destroys $\overline{<\text { respectively }>\text { good fortune and misery }}$ for the gods, demons and men. [6]

Compare this with Shukla's more felicitous rendering:

I bow to God Siva... a mere recollection of whose name is a source of fortune and end of misfortune for gods, demons and men. [Shukla 1976, xix]

More successful than the translation are the Supplements, that is, the detailed commentary and analysis of Bhāskara's commentary on each of the 33 verses of the second chapter of the Aryabhatīya [vol. 2.1-185]. Here one sees the historian of mathematics competently reconstructing the actual arithmetical and geometrical procedures envisaged by Bhāskara, and elucidating their relevance in solving astronomical problems. Especially valuable are the reconstruction of the mathematical tools [75-89]; the Rule of Three and its variants, and their application in astronomy [118-127]; and the Pulverizer and its astronomical applications [142-185].

The study is enriched by a number of useful appendices. Since mathematics arose in India as an aid to astronomical computations, 
Keller discusses most lucidly the basic assumptions and methodologies of Sanskrit astronomy in an appendix entitled 'Some Elements of Indian Astronomy' [186-195]. This is followed by several glossaries, an extensive bibliography and an index.

Notwithstanding the occasional unevenness of the translation, this is an important work, throwing as it does valuable light on the state of mathematics and its relation to astronomy in seventh-century India. This is also the first significant publication to appear in this century on the history of Indian mathematics.

\section{BIBLIOGRAPHY}

Chatterjee, B. 1974. 'A Glimpse of Āryabhața's Theory of Rotation of the Earth'. Indian Journal of History of Science 9:51-55.

Colebrooke, H. T. 1817. Algebra, with Arithmetic and Mensuration, from the Sanscrit of Brehmegupta and Bháscara. London. Repr. Classics of Indian Mathematics: Algebra with Arithmetic and Mensuration, From the Sanskrit of Brahmagupta and Bhāskara. Delhi 2005.

Datta, B. 1932. The Science of the Sulba: A Study of Early Hindu Geometry. Calcutta.

Datta, B. and A. N. Singh. 1935-1938. History of Hindu Mathematics: A Source Book. Bombay. Repr. Bombay 1962.

Hayashi, T., Kusuba, T., and Yano, M. 1997. Studies in Indian Mathematics: Series, Pi and Trigonometry (in Japanese). Tokyo.

Shukla, K. S. 1976. ed. Āryabhațina of Āryabhața with the Commentary of Bhāskara I and Someśvara. New Delhi. 